\title{
The Impact of Nigeria Microfinance Banks on Poverty Reduction: Imo State Experience
}

\author{
Okezie A. Ihugba, Bankoli Bankong, N. C. Ebomuche \\ Department of Economics, Alvan Ikoku Federal College of Education, P.M. B 1033, \\ Owerri, Imo State, Nigeria \\ E-mail address: ihugbablack@yahoo.com
}

\begin{abstract}
This paper attempts to provide a critical appraisal of the debate on the effectiveness of microfinance as an effective tool for eradicating poverty and also the history of microfinance banks in Nigeria. It argues that while microfinance has developed some innovative management and business strategies, its impact on poverty reduction remains in doubt. Micro finance impact on poverty reduction in Imo state was studied by a stratified sampling method in the selection of the customers. The study area was divided into 16 sample units based on the various local government areas in Imo state. Four (4) MFBs were purposefully selected from each of the 3 Senatorial Zones, making a total of 12 MFBs. In order to have unbiased selection of samples, Three Hundred and eighty two questionnaires (382) were randomly distributed to customers of these selected microfinance Banks in the three senatorial Zones as follows, namely: Owerri (82), Okigwe (100) and Orlu (200). The result revealed that majority of respondents were male constituting about $78 \%$ while women $22 \%$ and majority of the respondents were married (65\%), single (33\%) divorced ( $2 \%$ ). 137 of the respondents do not have any formal education, 67 possess primary school leaving certificate. 81 indicated having secondary school certificate. 71 with diploma / NCE and its equivalent. 28 of them have first degree certificate and above representing $36 \%$, $17 \%, 21 \%, 19 \%$ and $7 \%$ respectively. The monthly income brackets of the respondents show that One hundred and eleven (111) respondents (29\%) indicated earning $\$ 10,000 \$ 15,000,95$ respondents or 25 $\%$ indicated $\$ 15,001$ - $\$ 20,000$ as their income bracket, 94 or $24 \%$ were earning above $\$ 20,000$, while 84 (22\%) indicated earning below $\$ 10,000$. From the result, high income class has more capacity to save than poor dwelling in rural areas. The finding appears to support the predication of Economics theory of savings which argues that saving is a function of the level of income. The implication of this study is that the federal government of Nigeria and financial institutions in the country should take up the challenge of establishing bank branches in the rural areas or make formidable arrangement for supplying more credit to the rural dwellers.
\end{abstract}

Keywords: Micro finance; Micro credit; Poverty Reduction

\section{INTRODUCTION}

Since the 1970s, and especially since the new wave of microfinance in the 1990s, microfinance has come to be seen as an important development policy and a poverty reduction tool. Some argue (e.g. Littlefield et al. 2003; World Savings Bank Institute 2010) as reported by Adjei, Arun and Hossain (2009) that microfinance is a key tool to achieve the Millennium Development Goals (MDGs). The assumption is that if one gives more microfinance to poor people, poverty will be reduced. But the evidence regarding such impact is challenging and 
controversial, partly due to the difficulties of reliable and affordable measurement, of fungibility (Ashraf, Gine and Karla, 2008) the methodological challenge of proving causality (i.e. attribution), and because impacts are highly context-specific (Brau and Woller 2004; Hulme 1997; Hulme 2000; Makina and Malobola 2004:801; Sebstad and Cohen 2000).

This provision of funds in form of credit and microloans empowers the poor to engage in productive economic activities which can help boost their income level and thus alleviate poverty in the economy. Shreinner (2001) defines microfinance as efforts to improve the access to loans and to savings services for poor people. It is currently being promoted as a key development strategy for promoting poverty reduction / eradication and economic empowerment. It has the potential to effectively address material poverty, the physical deprivation of goods and services and the income to attain them by granting financial services to households who are not served by the formal banking sector. Microfinance is an effective development tool for promoting pro-poor growth and poverty reduction. Financial services enable poor and low income households to take advantage of economic opportunities, build assets, and reduce their vulnerability to external shocks that adversely affect their living standards.

The credit policy for the poor involves many practical difficulties arises from operation followed by financial institutions and the economic characteristics and financing needs of lowincome households. For example, commercial banking institutions require that borrowers have a stable source of income out of which principal and interest can be paid back according to the agreed terms. However, the income of many self employed households is not stable. A huge number of micro loans are needed to serve the poor, but banking institution prefers dealing with big loans in small numbers to minimize administration expenses. They also look for collateral with a clear title - which many low-income households do not have. In addition bankers tend to consider low income households a bad risk imposing exceedingly high information monitoring costs on operation.

Three features distinguish microfinance from other formal financial products. These are: (i) the smallness of loans advanced and or savings collected, (ii) the absence of asset-based collateral, and (iii) simplicity of operations (see appendix 1).

Ideally one can ascertain the impact of microfinance if the counterfactual what would have happened to a person who borrowed from a micro lender if he/she had not done so-can be easily tested. Many early studies compared borrowers with non-borrowers. But if borrowers are more entrepreneurial than those who do not borrow, such comparisons are likely to grossly overstate the effect of microcredit.

Questions regarding the impact of microfinance on the welfare and income of the poor have therefore been raised many times. According to Chowdhury (2009) two recent studies attempted to overcome the problem of self-selection (i.e., the likelihood of people with entrepreneurial skills borrowing) by using randomized sample selection methods. That is, participation in a programme is determined essentially by chance. Contrary to the usual claims, neither study found that microcredit reduced poverty. Microcredit may not even be the most useful financial service for the majority of poor people. The MIT study by Banerjee, Duflo, Glennerster and Kinnan (2009) found no impact on measures of health, education, or women's decision-making among the slum dwellers in the city of Hyderabad, India. Similarly, the study by Dean and Zinman (2009) as reported by Chowdhury (2009) which measured the probability of being below the poverty line and the quality of food that people ate, found no discernible effects. The most-cited source of evidence on the impacts of microfinance is the early set of studies collected by Hulme and Mosley (1996). The findings of these studies are provocative: poor households do not benefit from microfinance; it is only non-poor borrowers (with incomes 
above poverty lines) who can do well with microfinance and enjoy sizable positive impacts. More troubling is the finding that a vast majority of those with starting incomes below the poverty line actually ended up with less incremental income after getting micro-loans, as compared to a control group which did not get such loans.

Despite various studies, 'the question of the effectiveness and impact on the poor of (microfinance) programs is still highly in question' (Westover 2008). Roodman and Morduch (2009) reviewed studies on micro-credit in Bangladesh, and similarly conclude that ' 30 years into the microfinance movement we have little solid evidence that it improves the lives of clients in measurable ways'. Even the World Bank report Finance for all? (2007:99) indicates that 'the evidence from micro-studies of favorable impacts from direct access of the poor to credit is not especially strong.

Several factors have accounted for the persisting gap in access to financial services. For instance, the distribution of microfinance banks in Nigeria is not even, as many of the banks are concentrated in a particular section of the country, which investors perceived to possess high business volume and profitability. Also, many of the banks carried over the inefficiencies and challenges faced during the community banking era. In addition, the dearth of knowledge and skills in micro financing affected the performance of the MFBs. Furthermore, there are still inadequate funds for intermediation owing to lack of aggressive savings mobilization, inability to attract commercial capital, and the non establishment of the Microfinance Development Fund.

In Nigeria, a large percentage of the population is still excluded from financial services. The 2010 EFInA (Enhancing Financial Innovation \& Access) study revealed a marginal increase of those served by formal financial market from 35.0 percent in 2005 to 36.3 percent in 2010 , five (5) years after the launching of the microfinance policy. When those that had financial services from the informal sector such as savings clubs/pools, Esusu, Ajo, and money lenders were included, the total access percentage for 2010 was 53.7 percent which means that 46.3 percent or 39.2 million adult population were financially excluded in Nigeria (CBN, 2012).

Against the backdrop of concerns expressed by stakeholders and the need to enhance financial services delivery, the 2005 Microfinance Policy, Regulatory and Supervisory Framework for Nigeria was Revised in April, 2011, and in exercise of the powers conferred on the Central Bank of Nigeria by the provisions of Section 28, sub-section (1) (b) of the CBN Act 24 of 1991 (as amended) and in pursuance of the provisions of Sections 56-60(a) of the Bank and Other Financial Institutions Act (BOFIA) 25 of 1991 (as amended). The policy recognizes existing informal institutions and brings them within the supervisory purview of the CBN creating a platform for the regulation and supervision of microfinance banks (MFBs) through specially crafted Regulatory Guidelines.

\section{1. United Nations Mandate for Microfinance and Poverty Alleviation}

The World Summit for Social Development (WSSD) in March 1995 articulated a global commitment by Governments to eradicate poverty as an ethical, social, political and economic imperative. Poverty eradication was one of three core themes of WSSD. The Programme of Action affirmed the primacy of national responsibility for social development, including poverty eradication, but also called for international support to assist governments in developing strategies. The Programme of Action suggested ways to involve civil society in social development and to strengthen their capacities. It called on Governments to mobilize resources for social development, including poverty alleviation. The WSSD Programme of Action was to be implemented within the framework of international cooperation that integrated the follow-up to then recent and planned UN conferences relating to social development, for example, the Children's Summit in 1990, the Environment and Development Conference in 1992, the Human 
Rights Conference in 1993, the Population and Development Conference in 1994 and the Women's Conference in 1995.

The United Nations System Conference Action Plan (UNSCAP) designated poverty alleviation as the integrating theme for follow-up to world conferences. It called for UN system action in five areas:

1. Jobs and sustainable livelihood.

2. Regenerating the environmental issues.

3. The enabling environment.

4. Social service for all.

5. Arrangement of women and gender mainstreaming.

UNDP and UN Resident Coordinators were asked to coordinate UN system efforts in the five areas. UN development organizations have their own individual mandates.

Microfinance is one tool for poverty alleviation. The enabling environment influences the effectiveness of microfinance in the other four areas of poverty alleviation interventions. The UN organizations' mandates in the area of microfinance primarily lie in the area of technical assistance and demonstration of models that contribute effectively to poverty alleviation. The responsibility for provision of capital rests with governments, with support from bilateral donors and international financial institutions (Report of United Nations, 1995).

\section{2. Objectives of the Study}

The objectives of the study include:

1. To examine the poverty situation in Imo State, Nigeria.

2. To investigate the activities of microfinance banks in Imo State Nigeria.

3. To examines the effectiveness of microfinance banks in the alleviating of poverty in Imo state, Nigeria.

4. Provide suggestions on how to solve the problems as a step towards enhancing the economic status of members, thereby serving to reduce the rate of poverty alleviation among them.

5. To find out if the income class of an individual affects his or her savings in Imo State.

6. To find out if microfinance bank credit lead to poverty reduction in Imo state.

\section{3. Research Questions}

In order to pursue the objective of the study, the following research questions were formulated namely:

1. Do microfinance banks assist in promoting financial success of their customers?

2. Do microfinance banks help in encouraging savings in Imo state?

3. Do microfinance banks help in the alleviation of poverty in Imo State, Nigeria?

Hypotheses were thereby formulated and stated in the null form as stated below:

Ho: There is no significant relationship between the level of someone's income and access to financial services in Imo state.

$\mathrm{H}_{1}$ : There is a significant relationship between the level of someone's income and access to financial services in Imo state. 


\section{LITERATURE REVIEW}

\section{1. Microfinance in Nigeria}

The licensing of Microfinance Banks in Nigeria is the responsibility of the Central Bank of Nigeria. The practice of microfinance in Nigeria is culturally rooted and dates back several centuries. The traditional microfinance institutions provide access to credit for the rural and urban, low-income earners. They are mainly of the informal Self-Help Groups (SHGs) or Rotating Savings and Credit Associations (ROSCAs) types. Other providers of microfinance services include savings collectors and co-operative societies. The informal financial institutions generally have limited outreach due primarily to paucity of loanable funds.

In order to enhance the flow of financial services to Nigerian rural areas, Government has, in the past, initiated a series of publicly-financed micro/rural credit programmes and policies targeted at the poor. Notable among such programmes were the Rural Banking Programme, sectoral allocation of credits, a concessionary interest rate, and the Agricultural Credit Guarantee Scheme (ACGS). Other institutional arrangements were the establishment of the Nigerian Agricultural and Co-operative Bank Limited (NACB), the National Directorate of Employment (NDE), the Nigerian Agricultural Insurance Corporation (NAIC), the Peoples Bank of Nigeria (PBN), the Community Banks (CBs), and the Family Economic Advancement Programme (FEAP). In 2000, Government merged the NACB with the PBN and FEAP to form the Nigerian Agricultural Cooperative and Rural Development Bank Limited (NACRDB) to enhance the provision of finance to the agricultural sector. It also created the National Poverty Eradication Programme (NAPEP) with the mandate of providing financial services to alleviate poverty.

Despite these measures, it became increasingly evident that such governmental policies failed to grant financial access to those most in need (i.e. the rural poor) and that the programs were largely unsustainable.

The CBN at the sixth Annual Microfinance Conference and Entrepreneurship Awards held recently in Abuja said the microfinance development fund would be established in 2012 and would include both commercial and social components that would enhance its operations and outreach. The fund will also aim at improving access to affordable and sustainable sources of finance by microfinance institutions and microfinance banks.

This, being the second time that the $\mathrm{CBN}$ is making such pronouncement, the first one was pronounced at the 5th Annual Microfinance Conference and Entrepreneurship Awards in 2011, where Kingsley Moghalu, the deputy governor, financial system stability said the CBN would establish a microfinance development fund to promote accessibility to financial services for low income earners.

\section{2. Justification for the Establishment of Microfinance Banks in Nigeria}

Weak Institutional Capacity: The prolonged sub-optimal performance of many existing community banks, microfinance and development finance institutions is due to incompetent management, weak internal controls and lack of deposit insurance schemes. Other factors are poor corporate governance, lack of well defined operations and restrictive regulatory/supervisory requirements.

Weak Capital Base: The weak capital base of existing institutions, particularly the present community banks, cannot adequately provide a cushion for the risk of lending to micro entrepreneurs without collateral. This is supported by the fact that only 75 out of over 600 community banks whose financial statements of accounts were approved by the CBN in 2005 had up to N20 million shareholders' funds unimpaired by losses. Similarly, the NACRDB, with 
a proposed authorized share capital of N50.0 billion, has N10.0 billion paid up capital and only N1.3 billion shareholders' funds unimpaired by losses, as at December, 2004.

The Existence of a Huge Un-Served Market: The size of the unserved market by existing financial institutions is large. The average banking density in Nigeria is one financial institution outlet to 32,700 inhabitants. In the rural areas, it is $1: 57,000$, that is less than $2 \%$ of rural households have access to financial services. Furthermore, the 8 (eight) leading Micro Finance Institutions (MFIs) in Nigeria were reported to have mobilized a total savings of N222.6 million in 2004 and advanced N2.624 billion credit, with an average loan size of N8,206.90. This translates to about 320,000 membership-based customers that enjoyed one form of credit or the other from the eight NGO-MFIs. Their aggregate loans and deposits, when compared with those of community banks, represented percentages of 23.02 and 1.04, respectively. This, reveals the existence of a huge gap in the provision of financial services to a large number of active but poor and low income groups. The existing formal MFIs serve less than one million out of the over 40 million people that need the services. Also, the aggregate micro credit facilities in Nigeria account for about 0.2 percent of GDP and less than one percent of total credit to the economy. The effect of not appropriately addressing this situation would further accentuate poverty and slow down growth and development.

Economic Empowerment of the Poor, Employment Generation and Poverty Reduction: The baseline economic survey of Small and Medium Industries (SMIs) in Nigeria conducted in 2004 , indicated that the 6,498 industries covered currently employ a little over one million workers. Considering the fact that about 18.5 million ( $28 \%$ of the available work force) Nigerians are unemployed, the employment objective/role of the SMIs is far from being reached. One of the hallmarks of the National Economic Empowerment and Development Strategy (NEEDS) is the empowerment of the poor and the private sector, through the provision of needed financial services, to enable them engage or expand their present scope of economic activities and generate employment. Delivering needed services as contained in the Strategy would be remarkably enhanced through additional channels which the microfinance bank framework would provide. It would also assist the SMIs in raising their productive capacity and level of employment generation.

The Need for Increased Savings Opportunity: The total assets of the 615 community banks which rendered their reports, out of the 753 operating community banks as at end-December 2004, stood at N34.2 billion. Similarly, their total loans and advances amounted to N11.4 billion while their aggregate deposit liabilities stood at N21.4 billion for the same period. Also, as at end-December 2004, the total currency in circulation stood at N545.8 billion, out of which N458.6 billion or 84.12 per cent was outside the banking system. Poor people can and do save, contrary to general misconceptions. However, owing to the inadequacy of appropriate savings opportunities and products, savings have continued to grow at a very low rate, particularly in the rural areas of Nigeria. Most poor people keep their resources in kind or simply under their pillows. Such methods of keeping savings are risky, low in terms of returns, and undermine the aggregate volume of resources that could be mobilized and channeled to deficit areas of the economy. The microfinance policy would provide the needed window of opportunity and promote the development of appropriate (safe, less costly, convenient and easily accessible) savings products that would be attractive to rural clients and improve the savings level in the economy.

The Interest of Local and International Communities in Microfinancing: Many international investors have expressed interest in investing in the microfinance sector. Thus, the 
establishment of a microfinance framework for Nigeria would provide an opportunity for them to finance the economic activities of low income groups and the poor.

Utilization of SMEEIS Fund: As at December, 2004, only N8.5 billion (29.5\%) of the N28.8 billion Small and Medium Enterprises Equity Investment Scheme (SMEEIS) fund had been utilized. Moreover, $10 \%$ of the fund meant for micro credit had not been utilized due to lack of an appropriate framework and confidence in the existing institutions that would have served the purpose. This policy provides an appropriate vehicle that would enhance the utilization of the fund.

\section{3. Policy Objectives}

The specific objectives of this microfinance policy are the following:

1. Make financial services accessible to a large segment of the potentially productive Nigerian population which otherwise would have little or no access to financial services;

2. Promote synergy and mainstreaming of the informal sub-sector into the national financial system;

3. Enhance service delivery by microfinance institutions to micro, small and medium entrepreneurs;

4. Contribute to rural transformation; and

5. Promote linkage programmes between universal/development banks, specialized institutions and microfinance banks.

\section{4. Policy Targets}

Based on the objectives listed above, the targets of the policy are as follows:

1. To cover the majority of the poor but economically active population by 2020 thereby creating millions of jobs and reducing poverty.

2. To increase the share of micro credit as percentage of total credit to the economy from 0.9 percent in 2005 to at least 20 percent in 2020; and the share of micro credit as percentage of GDP from 0.2 percent in 2005 to at least 5 percent in 2020.

3. To promote the participation of at least two-thirds of state and local governments in micro credit financing by 2015.

4. To eliminate gender disparity by improving women's access to financial services by 5 $\%$ annually; and

5. To increase the number of linkages among universal banks, development banks, specialized finance institutions and microfinance banks by $10 \%$ annually.

\section{5. The Goals}

The establishment of microfinance banks has become imperative to serve the following purposes:

1. Provide diversified, affordable and dependable financial services to the active poor, in a timely and competitive manner, that would enable them to undertake and develop longterm, sustainable entrepreneurial activities;

2. Mobilize savings for intermediation;

3. Create employment opportunities and increase the productivity of the active poor in the country, thereby increasing their individual household income and uplifting their standard of living; 
4. Enhance organized, systematic and focused participation of the poor in the socioeconomic development and resource allocation process;

5. Provide veritable avenues for the administration of the micro credit programmes of government and high net worth individuals on a non-recourse case basis. In particular, this policy ensures that state governments shall dedicate an amount of not less than $1 \%$ of their annual budgets for the on-lending activities of microfinance banks in favour of their residents; and

6. Render payment services, such as salaries, gratuities, and pensions for various tiers of government.

\section{6. Establishment}

Private sector-driven microfinance banks shall be established. The banks shall be required to be well-capitalized, technically sound, and oriented towards lending, based on the cash flow and character of clients. There shall be two categories of Micro Finance Banks (MFBs), namely:

- Micro Finance Banks (MFBs) licensed to operate as a unit bank, and

- Micro Finance Banks (MFBs) licensed to operate in a state.

The recognition of these two categories of banks does not preclude them from aspiring to having a national coverage, subject to their meeting the prudential requirements. This is to ensure an orderly spread and coverage of the market and to avoid, in particular, concentration in areas already having large numbers of financial institutions.

An existing NGO which intends to operate an MFB can either incorporate a subsidiary MFB, while still carrying out its NGO operations, or fully convert into a MFB.

1. MFBs Licensed to Operate as a unit bank (a.k.a. Community Banks): MFBs licensed to operate as unit banks shall be community- based banks. Such banks can operate branches and/or cash centers subject to meeting the prescribed prudential requirements and availability of free funds for opening branches/cash centers. The minimum paid-up capital for this category of banks shall be N20.0 million for each branch.

2. MFBs Licensed to Operate in a State: MFBs licensed to operate in a State shall be authorized to operate in all parts of the State (or the Federal Capital Territory) in which they are registered, subject to meeting the prescribed prudential requirements and availability of free funds for opening branches. The minimum paid-up capital for this category of banks shall be N1.0 billion.

\section{7. Organic Growth Path for MFBs}

1. This policy recognizes that the current financial landscape of Nigeria is skewed against Micro, Small and Medium Enterprises (MSMEs) in terms of access to financial services. To address the imbalance, this policy framework shall promote an even spread of microfinance banks, their branches and activities, to serve the un-served but economically active clients in the rural and peri- urban areas.

2. The level of spread and saturation of the financial market shall be taken into consideration before approval is granted to an MFB to establish branches across the Local Government Areas and/or States, in fulfillment of the objectives of this policy. Specifically, an MFB shall be expected to have a reasonable spread in a Local Government Area or State before moving to another location, subject to meeting all necessary regulatory and supervisory requirements stipulated in the guidelines. This is 
to avoid concentration in already served areas and to ensure extension of services to the economically active poor, and to micro, small and medium enterprises.

3. In order to achieve the objectives of an organic growth path, a microfinance bank licensed to operate as a unit bank shall be allowed to open new branches in the same State, subject to meeting the prescribed prudential requirements and availability of minimum free funds of N20.0 million for each new branch. In fulfillment of this requirement, an MFB licensed to operate as a unit bank can attain the status of a State MFB by spreading organically from one location to another until it covers at least twothirds of the LGAs of that State. When an MFB has satisfactorily covered a state and wishes to start operations in another state, it shall obtain approval and be required to again grow organically by having at least N20 million free funds unimpaired by losses for each branch to be opened in the new state.

4. An MFB licensed to operate in a State shall be allowed to open a branch in another State, subject to opening branches in at least two-thirds of the local governments of the State it is currently licensed to operate in the provision of N20.0 million free funds and, if in the view of the regulatory authorities, it has satisfied all the requirements stipulated in the guidelines.

5. The regulations to be issued from time to time shall be such that would encourage the organic growth path of the MFBs at all times.

6. However, an MFB may wish to start operations as a State Bank from the beginning and therefore not wish to grow organically from branch to branch. Such an MFB may be licensed and authorized to operate in all areas of the state from the beginning subject to the provision of a total capital base of $\mathrm{N} 1$ billion. In other words, the preferred growth path for MFBs is the branch by branch expansion to become State Banks. But anyone wishing to start as a big state institution from the beginning can do so subject to availability of N1 billion and proven managerial competence.

\section{8. Ownership}

1. Microfinance banks can be established by individuals, groups of individuals, community development associations, private corporate entities, or foreign investors. Significant ownership diversification shall be encouraged to enhance good corporate governance of licensed MFBs. Universal banks that intend to set up any of the two categories of MFB as subsidiaries shall be required to deposit the appropriate minimum paid-up capital and meet the prescribed prudential requirements and if, in the view of the regulatory authorities, have also satisfied all the requirements stipulated in the guidelines.

2. No individual, group of individuals, their proxies or corporate entities, and/or their subsidiaries, shall establish more than one MFB under a different or disguised name.

\section{9. Participation of Existing Financial Institutions in Microfinance Activities}

1. Universal Banks: Universal banks currently engaging in microfinance services, either as an activity or product and do not wish to set up a subsidiary, shall be required to set up a department/ unit for such services and shall be subjected to the provisions of the MFB regulatory and supervisory guidelines. 
2. Community Banks: All licensed community banks, prior to the approval of this policy, shall transform to microfinance banks licensed to operate as a unit bank on meeting the prescribed new capital and other conversion requirements within a period of 24 months from the date of approval of this policy. Any community bank which fails to meet the new capital requirement within the stipulated period shall cease to operate as a community bank. A community bank can apply to convert to a microfinance bank licensed to operate in a State if it meets the specified capital and other conversion requirements.

3. Non-Governmental Organization - Micro Finance Institutions (NGO-MFIs): This policy recognizes the existence of credit-only, membership-based microfinance institutions which shall not be required to come under the supervisory purview of the Central Bank of Nigeria. Such institutions shall engage in the provision of micro credits to their targeted population and not to mobilize deposits from the general public. The registered NGO-MFIs shall be required to forward periodic returns on their activities to the CBN. NGO-MFIs that wish to obtain the operating license of a microfinance bank shall be required to meet the specified provisions as stipulated in the regulatory and supervisory guidelines.

4. Transformation of the Existing NGO-MFIs: Existing NGO-MFIs which intend to operate an MFB can either incorporate a subsidiary MFB while still carrying out its NGO operations or fully convert into an MFB. NGO-MFIs that wish to convert fully into a microfinance bank must obtain an operating license and shall be required to meet the specified provisions as stipulated in the regulatory and supervisory guidelines.

\section{10. Justification for the Capital Requirements}

1. The present capital base of N5 million for community banks has become too low for effective financial intermediation. Indeed, to set up a community bank, at least N5 million is required for the basic infrastructure, leaving zero or a negative balance for banking operations. From a survey of community banks, an operating fund of N50 million is about the minimum capital (own capital and deposits) a community bank needs to provide effective banking services to its clients. However, it is recognized that since many community banks are based in rural areas, their promoters may not be able to effectively raise N50 million as shareholders' funds. Hence, the stipulation of N20 million as shareholders' funds for the unit microfinance banks. The banks are expected to engage in aggressive mobilization of savings from micro-depositors to shore up their operating funds.

2. A State coverage microfinance bank that would operate multiple branches would be expected to take off with funds sufficient to operate a full branch in at least two-thirds of the Local Government Areas in that State. Hence, a minimum paid-up capital of N1.0 billion shall be required to obtain the license to operate a State coverage MFB. Expansion to another State shall be subject to the provision of N1.0 billion minimum shareholders' funds unimpaired by losses, and after opening branches in at least two-thirds of the Local Government Areas of the State it is currently licensed to operate in, and if in the view of the regulatory authorities, it has satisfied all the requirements stipulated in the guidelines.

3. The experience of other countries sheds light on the level of capitalization required for microfinance banks. In most countries, the level of capitalization depends on the geographical coverage of the banks, and for some countries, even for a particular scope 
of coverage (district or province), the population and volume of business of the area further determine the level of capitalization. The capitalization requirements in other countries were also considered in arriving at the capitalization levels for the two categories of MFBs in this policy.

\section{BRIEF HISTORY OF IMO STATE}

Imo State is one of the 36 states of Nigeria and lies to the south of Nigeria with Owerri as its capital and largest city. Imo State came into existence in 1976 along with other new states created under the leadership of the late military ruler of Nigeria, Murtala Muhammad, having been previously part of East-Central State. The State lies between latitudes $5^{\circ} 45^{\mathrm{ee}} \mathrm{N}$ and $6^{\circ} 35^{\mathrm{e}} \mathrm{N}$ of the equator and longitudes $6^{\circ} 35^{\mathrm{ec}} \mathrm{E}$ and $7^{\circ} 28^{\mathrm{ec}} \mathrm{E}$ of the Greenwich Meridian (Microsoft Corporation, 2009). The State is located in the Southeastern area of Nigeria and shares common boundaries with Abia State on the east and northeast, Rivers State on the south, and Anambra State on the west and northwest. It has a total land area of about 5,067.20 km2 (Ministry of Lands Owerri, 1992). Besides Owerri, Imo State's major towns are Isu, Njaba, Okigwe, Oguta, Orlu, Mbaise, Mbano, Mbieri, Orodo and Orsu.

The population of Imo State is estimated at 4.05 million by 2007, with about half of this as children under 18 years. If you adjust for the Diaspora population (that is, all those living outside of Imo state), the citizens of Imo might be in the order of 6-7 million. If Imo State were a country, it would probably rank number 32 or 38 out of 54 African countries in terms of population. The estimate is that probably 2-3 million Imo citizens live outside of Imo State as Diaspora and making remittances to the home residents.

Imo state had the highest adult literacy in Nigeria during the 1990s (75\%). Most of the tertiary institutions are located around the state capital Owerri, and include: Imo State University, Owerri; Federal University of Technology, Owerri; Alvan Ikoku Federal College of Education, Owerri; Michael Okpara College of Agriculture, Umuagwo; The Polytechnic, Nekede. The concentration has implications for tourism and educational quality.

Imo state was ranked $5^{\text {th }}$ in the country in order of states total GDP (PPP) in 2007; see appendix 3. According to Soludo (2008) agriculture is the major occupation of the rural population. Commerce, industry, and services constitute much of the economic activity of the urban dwellers. The people of Imo state are very entrepreneurial and largely dominate the informal pharmaceutical drug market in Nigeria. The Diaspora population makes remittances to the home residents. Remittances plus income generated within the state help to raise per capita consumption and standard of living thus making Imo state one of the least poor states in Nigeria. For example, poverty incidence has declined from $56.2 \%$ in 1996 to $27 \%$ in 2004 . The number of commercial bank branches in the state and the size of bank deposits reflect the size of economic activities within the state. As at March 2008, there were 69 branches of commercial banks out of 4,606 in Nigeria, while it accounts for barely 1 percent of total deposits. Out of 600 microfinance banks in Nigeria, Imo state had 40 as at 31ST DECEMBER, 2007, reflecting the strength of communities and capacity for self-help.

Aside from the natural resource endowments, Imo state has immense potential for tourism. For example, the top ten attractions include: Oguta Wonder Lake Resort and conference centre, Oguta; The Natural Springs located at Onicha, Ezinihitte Mbaise; Nekede Zoological garden and forestry reserve; The rolling hills at Okigwe; Monkey colonies at Lagwa, Aboh Mbaise, and Omuma and Aji, Oru East LGA; Ezeama mystic spring at Isu Njaba; Ngwu springs at Nkwerre 
near Oriukwu, Dikenafai, Ideato South LGA; Njaba springs; Abadaba Lake; and the blue lake at Oguta.

\section{METHODOLOGY}

\section{1. Area of Study}

The study was carried out in Imo State, Nigeria. Imo State was selected because of proximity, cost and familiarity. The State has three geopolitical zones (Orlu, Owerri, and Okigwe zones). It is also delineated into 27 local government areas. The population of the state is $3,934,899$ persons with many subsisting in farming (NBS, 2007).

\section{2. Data Source}

Both secondary and primary data were used in generating information on the effectiveness of microfinance banks in alleviating poverty as expressed by their customers in Imo State, Nigeria. A questionnaire was designed titled "Questionnaire on the Impact of Microfinance Banks in poverty reduction in Imo State (QIMBPRIS)". Descriptive survey was adopted for the study. According to Adewumi (1981) as reported by Yahaya, Osemene and Abdulraheem (2011) the survey method was chosen because of its inherent advantages over other research methods.

\section{3. Sampling Method}

A stratified sampling method was used in the selection of the customers that expressed their viewed on the effectiveness microfinance banks in alleviating poverty in Imo state, Nigeria. In order to have unbiased selection of samples, the study area was divided into 16 sample units based on the various local government area in Imo state, Nigeria. The population of the study comprises 40 microfinance Banks (MFBs) in the 3 Senatorial Zones of the study area, which consists of 27 Local Government Areas (LGAs). Four (4) MFBs were purposefully selected from each of the 3 Senatorial Zones, making a total of 12 MFBs. One Hundred and Twenty questionnaires (120) were randomly distributed to customers of these selected microfinance Banks in the three senatorial Zones as follows, namely: Owerri (82), Okigwe (100) and Orlu (200). Orlu has the highest concentration of MFBs therefore having more customers (Orlu, 65 $\%$ : Owerri, $25 \%$ \& Okigwe, $10 \%$ ) see figure 1 . This is probably due to the fact that it has the highest number of LGA's (Twelve out of 27) and majority of the MFBs were licensed to Operate as a unit bank (a.k.a. Community Banks). Commercial banks are concentrated more in Okigwe and Owerri than Orlu. However, only eighty (80) questionnaires were properly filled and used for analysis. Respondents were asked to respond to the questions contained in the questionnaire by indicating level of relevance of the implicated variables. Data generated from the survey were analyzed using descriptive and inferential statistics such as percentage, mean, standard deviation, t- test statistics and Analysis of Variance (ANOVA) at 0.05 alpha level.

\section{4. Method of Data Analysis}

Average monthly income of the respondents was used by IPAR (2007) to proxy poverty. Respondents with income level below \$2 per day will proxy rural poor because Sani (2008) argued that extreme poor are those with daily income level of less than one US dollar. This is in line with the millennium declaration popularly known as MDGs. Therefore respondents with income level above \$2 per day were coded I and 0 if otherwise. IPAR (2007) further used the level of financial exposure of the respondents on Saving Account. Current Account, Fixed 
Deposit, Loans, Automated Transaction Machine (ATM)/Credit/Debit Card, Loan, Insurance, Mobile Banking, Internet, Banking, Shares and Pension to proxy access to finance. They coded 0 for individuals who didn't answer the question or did not know the answer. I for individuals that had never used the product, 2 for individuals who used the product before, 3 for individuals who have other members of the household using the product in question and 4 was allocated to individuals who currently have the product. Nevertheless, in this study 0 was coded for the respondents unanswered the question or do not know the answer. I was awarded to individuals who had never used the product. 2 for individuals who used the product before and 3 for individuals who are currently using the product.

Logit model was used to analyze the influence of independent variables (financial services) on the dependent variable (level of income). The model is given below:

$$
\operatorname{Pr}\left(Y_{1}-1\right) \quad F\left(\frac{x}{b}\right)
$$

where

$$
\begin{aligned}
& \operatorname{Pr}\left(Y_{1}\right)=\operatorname{Pr} \text { obability of income of the respondents, N10,000 and above } \\
& X=\text { Vector of } \exp \text { lanatory var iables } \\
& b=\text { Parameter to be estimated } \\
& F=\text { Cumulative } \log \text { istic functions also knownas log odds. }
\end{aligned}
$$

Since the respondents exhibit different categories of income level, we applied multinomial logit model to ascertain how the degree of financial services usage vary among the different income categories of the respondents. The respondents were categorized into four income brackets below $\$ 10.000$. $\$ 10,001 \$ 15,000$. $\$ 15,001 \$ 20,000$ and $\$ 20,001$ and above. Therefore the model is further modified to accommodate different income brackets of the respondents as such: the model is given in turn.

$$
\begin{array}{ll}
\operatorname{Pr}(>10000) & F\left(X_{1} \beta\right) . \\
\operatorname{Pr}(10000150001) & F\left(X_{1} \varphi\right) . \\
\operatorname{Pr}(15001 \text { 20000 1) } & F\left(X_{1} \Omega\right) . \\
\operatorname{Pr}(20001 \text { and above } 1) & F\left(X_{1} \sigma\right) .
\end{array}
$$

where $\beta \varphi \Omega$ and $\sigma$ are parameters to be estimated and $\mathrm{F}$ is the normal cumulative distributions function.

\section{RESULTS AND DISCUSSION}

The result is divided into two parts i.e. descriptive results and inferential results. 
Table 1. Demographic distributions of the respondents.

\begin{tabular}{|c|c|c|}
\hline Variables & Frequency & Percent \\
\hline \multicolumn{3}{|l|}{ Sex } \\
\hline Male & 298 & 78 \\
\hline Female & 86 & 22 \\
\hline \multicolumn{3}{|l|}{ Marital status } \\
\hline Single & 125 & 33 \\
\hline Married & 251 & 65 \\
\hline Divorced & 8 & 2 \\
\hline \multicolumn{3}{|c|}{ Educational qualifications } \\
\hline No formal education & 136 & 37 \\
\hline Primary school & 67 & 17 \\
\hline Secondary school & 81 & 21 \\
\hline Equivalent diploma & 71 & 19 \\
\hline Degree and above & 28 & 7 \\
\hline \multicolumn{3}{|l|}{ Occupation } \\
\hline No response & 7 & 2 \\
\hline Farming & 167 & 44 \\
\hline Business & 120 & 31 \\
\hline Civil servant & 90 & 23 \\
\hline \multicolumn{3}{|l|}{ Income range in Naira } \\
\hline Below 10,000 & 84 & 22 \\
\hline $10,001-15,000$ & 111 & 29 \\
\hline $15,001-20,000$ & 95 & 25 \\
\hline Above 20,000 & 94 & 24 \\
\hline
\end{tabular}

Source: Field survey, 2012.

In Table 1 above, it shows that 298 respondents were male while 86 respondents were female representing $78 \%$ and $22 \%$ respectively. The table also shows information regarding the marital status of the respondents and it indicated that majority of the respondents were married, numbering 251, while 125 respondents were single and only 8 were divorced representing 65 
$\%, 33 \%$ and $2 \%$ respectively. Moreover, data pertaining to educational qualifications of the respondents shows that 137 of the respondents do not have any formal education, 67 possess primary school leaving certificate. 81 indicated having secondary school certificate. 71 with diploma / NCE and its equivalent. 28 of them have first degree certificate and above representing $36 \%, 17 \%, 21 \%, 19 \%$ and $7 \%$ respectively. This data coincides with Beck et al, (2006) assertion that finance appears inaccessible because of high rate of illiteracy in rural areas. Table I above, further shows the frequency of the occupational distribution of the respondents. It was observed that 7 respondents $(2 \%)$ did not respond to the question, 167 (44\%) were farmers, 90 $(23 \%)$ were civil servant, 120 (31\%) indicated business as their occupation. In order to avoid multiplicity of response, respondents that affiliated to more than one occupation were only asked to give their major one. We similarly depict the monthly income brackets of the respondents from the above table. One hundred and eleven (111) respondents $(29 \%)$ indicated earning $\$ 10,000 \$ 15,000,95$ respondents or $25 \%$ indicated $\$ 15,001$ - $\$ 20,000$ as their income bracket, 94 or $24 \%$ were earning above $\$ 20,000$, while 84 (22\%) indicated earning below $\$ 10,000$.

Table 2. Summary of Multinomial Logit Regression.

\begin{tabular}{|c|c|c|c|c|}
\hline Variables & $\mathbf{( 4 )}$ & $\mathbf{( 5 )}$ & $\mathbf{( 6 )}$ & probability \\
\hline Saving account & $\begin{array}{c}-0.27 \\
(-1.28)\end{array}$ & $\begin{array}{c}-0.56 \\
(-1.96)\end{array}$ & $\begin{array}{c}-0.56 \\
(-2.60)\end{array}$ & 0.202 \\
\hline Current account & $\begin{array}{c}0.10 \\
(0.44)\end{array}$ & $\begin{array}{c}0.10 \\
(0.44)\end{array}$ & $\begin{array}{c}0.25 \\
(1.08)\end{array}$ & 0.692 \\
\hline Fixed deposit & $\begin{array}{c}0.74 \\
(1.67)\end{array}$ & $\begin{array}{c}0.73 \\
(1.44)\end{array}$ & $\begin{array}{c}0.54 \\
(1.19)\end{array}$ & 0.234 \\
\hline Loan & $\begin{array}{c}0.01 \\
(0.02)\end{array}$ & $\begin{array}{c}-0.88 \\
(-2.60)\end{array}$ & $\begin{array}{c}-0.64 \\
(-2.07)\end{array}$ & 0.985 \\
\hline ATM debit card & $\begin{array}{c}0.06 \\
(0.27)\end{array}$ & $\begin{array}{c}-0.08 \\
(-0.32)\end{array}$ & $\begin{array}{c}0.29 \\
(1.20)\end{array}$ & 0.787 \\
\hline Insurance & $\begin{array}{c}-1.12 \\
(-1.57)\end{array}$ & $\begin{array}{c}-1.12 \\
(-1.57)\end{array}$ & $\begin{array}{c}0.18 \\
(0.36)\end{array}$ & 0.721 \\
\hline Microfinance & $\begin{array}{c}0.37 \\
(1.25)\end{array}$ & $\begin{array}{c}0.37 \\
(1.25)\end{array}$ & $\begin{array}{c}-0.6 \\
(-0.20)\end{array}$ & 0.840 \\
\hline Mobile banking & $\begin{array}{c}0.93 \\
(2.27)\end{array}$ & $\begin{array}{c}0.93 \\
(2.27)\end{array}$ & $\begin{array}{c}-0.69 \\
(-1.37)\end{array}$ & 0.172 \\
\hline Pseudo R ${ }^{2}$ & & & 0.40 & \\
\hline L R Chi ${ }^{2}$ & & & 42.03 & \\
\hline No of observation & & 384 & \\
\hline
\end{tabular}

Indicate significance at $10.5 \& 1$ percent probability levels, Z-ratios in parenthesis

Table 2 above shows the summary of multinomial logit regression results. It could be discerned from the result that the estimated coefficient of saving is negative but not significant in equation 4 while the estimated coefficient is significant in equation 5 and 6 . The result means that high income class has more capacity to save than poor dwelling in rural areas. The finding appears to support the predication of Economics theory of savings which argues that saving is a 
function of the level of income. On the contrary the estimated coefficients of current account and fixed deposit are positive but statistically insignificant in all models however both have 69 $\%$ and $23 \%$ probabilities of reducing poverty. Moreover, the estimated coefficient in equation 4 and 5 are and statistically significant at $1 \%$ and $5 \%$ level of significance respectively. The estimated coefficient of loan has the highest probability (98\%) of reducing poverty in rural areas. This finding tends to supports Burgess and Pande (2003). Who asserted that access to formal finance is critical for enabling the poor to transform their production systems and thus exit poverty? Access to finance through credit assists the poor not only to smooth their consumption expenditure but also to build their assets, which enhance their productive capacity (IPAR, 2007).

Furthermore the estimated coefficients of ATM and insurance are not statistically significant in all equation but have approximately $79 \%$ and $72 \%$ likelihood of reducing poverty in rural areas respectively. Similarly, the estimated coefficient of microfinance is statistically insignificant in all equations with $84 \%$ probability of reducing poverty in rural areas. The estimated coefficients of mobile banking are positive and significant at $5 \%$ level of significance in equation 3 and 4 respectively. Moreover, the estimated coefficient in equation 5 is not statistically significant. The coefficient has $17 \%$ probability of reducing poverty in rural areas. The overall model is adequate given by significant $\mathrm{LR} \mathrm{Ch}^{2}$ value at $1 \%$ level of significance so also $40 \%$ variations in dependent variable is jointly explained by independent variables as shown by Pseudo $\mathrm{R}^{2}$ value.

\section{CONCLUSION AND RECOMMENDATION}

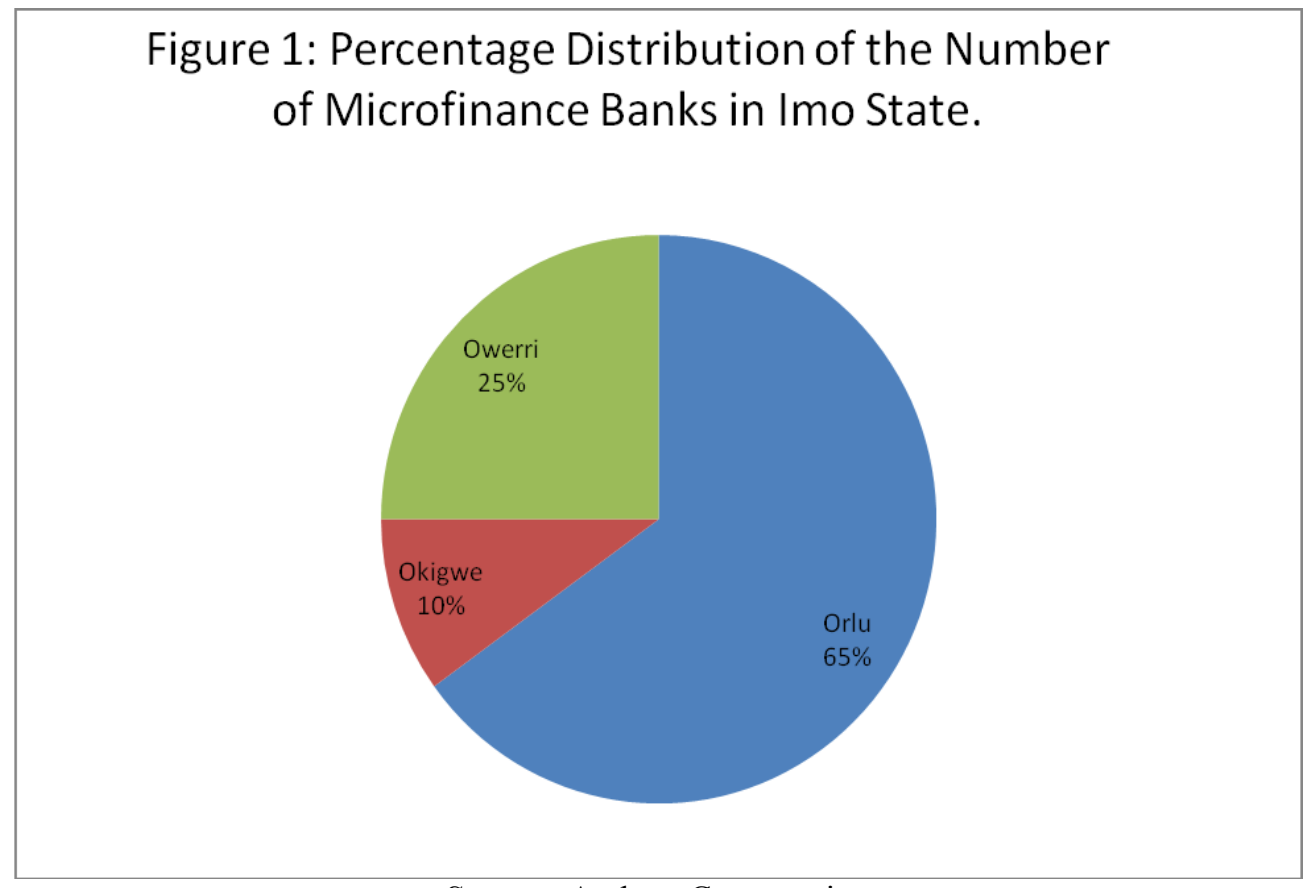

Source: Authors Computation

The study found that access to formal financial services increases with level of respondents' income in rural areas and also most of the variables that were examined indicated a very high probability of reducing poverty. It could therefore be concluded that enhancing access to formal finance especially credit has a high likelihood of reducing poverty in rural areas. The implication of this study is that the federal government of Nigeria and financial institutions 
in the country should take up the challenge of establishing bank branches in the rural areas or make formidable arrangement for supplying more credit to the rural dwellers. This study suggests that group lending strategy of Grammen Bank of Bangladesh could be copied since the bank recorded very low default rate. This is based on the premise that the government policy priority is poverty reduction.

\section{ANNEX 1}

Distinguishing Features between a Microfinance Banks and Universal Banks

\begin{tabular}{|c|c|c|c|c|}
\hline & Criteria & $\begin{array}{c}\text { Microfinance Banks } \\
\text { Licensed To Operate } \\
\text { In As A Unit Bank In } \\
\text { A LGA (A.K.A. } \\
\text { Community Banks) } \\
\end{array}$ & $\begin{array}{c}\text { Microfinance Banks } \\
\text { Licensed To Operate In } \\
\text { A State }\end{array}$ & Universal Banks \\
\hline 1. & $\begin{array}{c}\text { Minimum paid-up } \\
\text { capital/shareholders' } \\
\text { funds }\end{array}$ & $\begin{array}{c}\mathrm{N} 20.0 \text { million } \\
\text { (increased from N5.0 } \\
\text { million) }\end{array}$ & N1.0 billion & N25.0 billion \\
\hline 2. & $\begin{array}{l}\text { Scope of Activities } \\
\text { covered by Licence }\end{array}$ & $\begin{array}{l}\text { To operate within a } \\
\text { Local Government } \\
\text { Area. Not to engage in } \\
\text { sophisticated banking } \\
\text { services, such as forex } \\
\text { business }\end{array}$ & $\begin{array}{l}\text { To operate within a State } \\
\text { Not to engage in } \\
\text { sophisticated banking } \\
\text { services, such as forex } \\
\text { business but can receive } \\
\text { tenured loans and equity } \\
\text { from abroad }\end{array}$ & $\begin{array}{c}\text { To operate } \\
\text { nationally and in } \\
\text { international } \\
\text { markets To } \\
\text { operate forex } \\
\text { transactions and } \\
\text { domiciliary } \\
\text { Accounts for } \\
\text { customers }\end{array}$ \\
\hline 3. & $\begin{array}{l}\text { Limitation on credit to an } \\
\text { individual or } \\
\text { company }\end{array}$ & $\begin{array}{c}\text { Credit subject to a } \\
\text { single obligor limit of } \\
1 \% \text { for an } \\
\text { individual/corporate } \\
\text { entity and } 5 \% \text { for a } \\
\text { group }\end{array}$ & $\begin{array}{l}\text { Credit subject to single } \\
\text { obligor limit of } 1 \% \text { for } \\
\text { an individual/corporate } \\
\text { entity and } 5 \% \text { for a } \\
\text { group }\end{array}$ & $\begin{array}{l}\text { Single obligor } \\
\text { limit applies }\end{array}$ \\
\hline 4. & $\begin{array}{l}\text { Limitations on deposits } \\
\text { from an individual or a } \\
\text { company } \\
\end{array}$ & No limit & No limit & No limit \\
\hline 5. & $\begin{array}{l}\text { Access to public } \\
\text { sector deposits }\end{array}$ & $\begin{array}{l}\text { Permitted for only } \\
\text { microcredit } \\
\text { programmes on a non- } \\
\text { recourse basis and for } \\
\text { payment purposes }\end{array}$ & $\begin{array}{l}\text { Permitted for only } \\
\text { micro-credit programmes } \\
\text { on a nonrecourse basis } \\
\text { and for payment } \\
\text { purposes }\end{array}$ & Permitted \\
\hline 6. & Cheque writing accounts & $\begin{array}{l}\text { Cheque issuing } \\
\text { customized to the } \\
\text { correspondence bank }\end{array}$ & $\begin{array}{c}\text { Cheque issuing } \\
\text { customized to the } \\
\text { correspondence bank }\end{array}$ & $\begin{array}{c}\text { Cheque issuing } \\
\text { Permitted }\end{array}$ \\
\hline 7. & Geographical coverage & In rural and urban areas & $\begin{array}{c}\text { Must operate in both } \\
\text { rural and urban areas } \\
\text { within a State in a } \\
\text { proportion prescribed by } \\
\text { the CBN }\end{array}$ & $\begin{array}{l}\text { All parts of } \\
\text { Nigeria and } \\
\text { foreign branches } \\
\text { and subsidiaries }\end{array}$ \\
\hline
\end{tabular}

Source: Central Bank of Nigeria, Abuja, December 2005. 


\section{ANNEX 2}

\section{COMMUNITY BANKS CONVERTED TO MICROFINACE BANKS AS AT 31ST DECEMBER, 2007}

\begin{tabular}{|c|c|c|c|c|}
\hline S/NO & NAME & OLD NAME & ADDRESS & ZONE \\
\hline 1. & $\begin{array}{l}\text { Akokwa Microfinance } \\
\text { Bank Limited }\end{array}$ & $\begin{array}{l}\text { Akokwa Community } \\
\text { Bank }\end{array}$ & $\begin{array}{l}\text { Orie-Akokwa Market Square, } \\
\text { Ideato North Lga, Imo State }\end{array}$ & Orlu \\
\hline 2. & $\begin{array}{l}\text { All Workers Microfinance } \\
\text { Bank Limited }\end{array}$ & $\begin{array}{c}\text { All Workers } \\
\text { Community Bank }\end{array}$ & $\begin{array}{l}\text { Ugisi Orji, Uratta, Owerri, Imo } \\
\text { State }\end{array}$ & Owerri \\
\hline 3. & $\begin{array}{l}\text { Alvana Microfinance } \\
\text { Bank Limited }\end{array}$ & $\begin{array}{l}\text { Alvana Community } \\
\text { Bank }\end{array}$ & $\begin{array}{c}\text { Alvan Ikoku College Of } \\
\text { Education, Owerri, Imo State }\end{array}$ & Owerri \\
\hline 4. & $\begin{array}{c}\text { Amaifeke Microfinance } \\
\text { Bank Limited } \\
\end{array}$ & $\begin{array}{c}\text { Amaifeke } \\
\text { Community Bank }\end{array}$ & $\begin{array}{l}\text { 95, Ihioma Road, Amaifeke Orlu, } \\
\text { Imo State }\end{array}$ & Orlu \\
\hline 5. & $\begin{array}{l}\text { Amram Microfinance } \\
\text { Bank Limited }\end{array}$ & & $\begin{array}{l}\text { 3, Nekede Road, Owerri, Imo } \\
\text { State }\end{array}$ & Owerri \\
\hline 6. & $\begin{array}{l}\text { Amucha Microfinance } \\
\text { Bank Limited }\end{array}$ & $\begin{array}{l}\text { Amucha Community } \\
\text { Bank }\end{array}$ & $\begin{array}{c}\text { Bakn House, Amucha, Via Orlu } \\
\text { Njaba, Imo State }\end{array}$ & Orlu \\
\hline 7. & $\begin{array}{c}\text { Arondizuogu } \\
\text { Microfinance Bank } \\
\text { Limited } \\
\end{array}$ & $\begin{array}{c}\text { Arondizuogu } \\
\text { Community Bank }\end{array}$ & $\begin{array}{c}\text { P.O.Box 101, Arodisuogu, Ideato } \\
\text { North Lga, Imo State }\end{array}$ & Orlu \\
\hline 8. & $\begin{array}{c}\text { Atta Nwambiri } \\
\text { Microfinance Bank } \\
\text { Limited }\end{array}$ & $\begin{array}{c}\text { Atta Nwambiri } \\
\text { Community Bank }\end{array}$ & $\begin{array}{c}\text { Afor Atta Postal Agency, Orlu, } \\
\text { Imo State }\end{array}$ & Orlu \\
\hline 9. & $\begin{array}{l}\text { ATTA NWAMBIRI } \\
\text { Microfinance Bank } \\
\text { Limited } \\
\end{array}$ & $\begin{array}{l}\text { ATTA NWAMBIRI } \\
\text { Community Bank }\end{array}$ & $\begin{array}{c}\text { Afor Atta Postal Agency, Orlu, } \\
\text { Imo State }\end{array}$ & Orlu \\
\hline 10 & $\begin{array}{c}\text { DIKENAFAI } \\
\text { Microfinance Bank } \\
\text { Limited } \\
\end{array}$ & $\begin{array}{c}\text { DIKENAFAI } \\
\text { Community Bank }\end{array}$ & $\begin{array}{c}\text { Dikenafai Postal Agency, Ideato } \\
\text { South Lga, Imo State }\end{array}$ & Orlu \\
\hline 11 & $\begin{array}{c}\text { EBENATOR } \\
\text { Microfinance Bank } \\
\text { Limited } \\
\end{array}$ & $\begin{array}{c}\text { EBENATOR } \\
\text { Community Bank }\end{array}$ & $\begin{array}{l}\text { Oduga Square, Amaelu, } \\
\text { Ebenator, Imo State }\end{array}$ & Orlu \\
\hline 12 & $\begin{array}{c}\text { EKWEMA Microfinance } \\
\text { Bank Limited }\end{array}$ & $\begin{array}{c}\text { EKWEMA } \\
\text { Community Bank }\end{array}$ & $\begin{array}{c}\text { 1, Tetlow Road, Owerri, Imo } \\
\text { State }\end{array}$ & Owerri \\
\hline 13 & $\begin{array}{l}\text { ETITI Microfinance Bank } \\
\text { Limited }\end{array}$ & $\begin{array}{l}\text { UMUIHI Community } \\
\text { Bank }\end{array}$ & $\begin{array}{l}\text { Isinweke-Ihitte, Uboma Lga, } \\
\text { Etiti, Imo State }\end{array}$ & OKIGWE \\
\hline 14 & $\begin{array}{l}\text { FUTO Microfinance Bank } \\
\text { Limited } \\
\end{array}$ & $\begin{array}{l}\text { FUTO Community } \\
\text { Bank } \\
\end{array}$ & $\begin{array}{c}\text { Federal University Of } \\
\text { Technology, Owerri, Imo State }\end{array}$ & Owerri \\
\hline 15 & $\begin{array}{c}\text { GREENLAND } \\
\text { Microfinance Bank } \\
\text { Limited } \\
\end{array}$ & $\begin{array}{c}\text { AKATTA } \\
\text { Community Bank }\end{array}$ & $\begin{array}{c}\text { Afor Market Square, Akatta, } \\
\text { Oru-East Lga, } 21 \text { Orlu Road, } \\
\text { Amaigbo, Imo State }\end{array}$ & Orlu \\
\hline 16 & $\begin{array}{l}\text { IDEATO-SOUTH } \\
\text { Microfinance Bank } \\
\text { Limited } \\
\end{array}$ & $\begin{array}{l}\text { IDEATO-SOUTH } \\
\text { Community Bank }\end{array}$ & $\begin{array}{c}\text { C/O Mrs Nkeiru Ekekwe, St } \\
\text { Joseph's Catholic Church,Ntueke, } \\
\text { Ideato South }\end{array}$ & Orlu \\
\hline 17 & $\begin{array}{l}\text { IHIOMA Microfinance } \\
\text { Bank Limited } \\
\end{array}$ & $\begin{array}{l}\text { IHIOMA Community } \\
\text { Bank } \\
\end{array}$ & $\begin{array}{c}\text { 245, Ihioma Road, Orlu, Imo } \\
\text { State }\end{array}$ & Orlu \\
\hline 18 & $\begin{array}{l}\text { IHITTE Microfinance } \\
\text { Bank Limited }\end{array}$ & $\begin{array}{l}\text { IHITTE Community } \\
\text { Bank }\end{array}$ & $\begin{array}{l}\text { Box 10, Orie Ihitte Ezinihitte } \\
\text { Mbaise Lga, Imo State }\end{array}$ & Owerri \\
\hline 19 & $\begin{array}{l}\text { IMSU Microfinance Bank } \\
\text { Limited }\end{array}$ & $\begin{array}{c}\text { IMSU Community } \\
\text { Bank } \\
\end{array}$ & $\begin{array}{l}\text { Imo State University, Owerri, } \\
\text { Imo State }\end{array}$ & Owerri \\
\hline 20 & $\begin{array}{l}\text { ISU Microfinance Bank } \\
\text { Limited }\end{array}$ & $\begin{array}{l}\text { AMURIE OMANZE } \\
\text { CB. }\end{array}$ & $\begin{array}{l}\text { Amurie Omanze Community, Isu } \\
\text { Lga, Imo State }\end{array}$ & Orlu \\
\hline 21 & $\begin{array}{l}\text { MERIT Microfinance } \\
\text { Bank Limited }\end{array}$ & $\begin{array}{c}\text { AMAIGBO } \\
\text { Community Bank }\end{array}$ & $\begin{array}{c}\text { 21, Orlu Road, Amaigbo, Imo } \\
\text { State }\end{array}$ & Orlu \\
\hline 22 & $\begin{array}{l}\text { MGBIDI Microfinance } \\
\text { Bank Limited }\end{array}$ & $\begin{array}{l}\text { MGBIDI Community } \\
\text { Bank }\end{array}$ & $\begin{array}{l}\text { Owerri-Onitsha Road, Mgbidi, } \\
\text { Imo State }\end{array}$ & Orlu \\
\hline
\end{tabular}




\begin{tabular}{|c|c|c|c|c|}
\hline 23 & $\begin{array}{l}\text { NATIONS Microfinance } \\
\text { Bank Limited } \\
\end{array}$ & $\begin{array}{c}\text { HOMETRUST } \\
\text { Community Bank } \\
\end{array}$ & $\begin{array}{c}\text { 76, Orlu Road, Nkwere, Imo } \\
\text { State } \\
\end{array}$ & Orlu \\
\hline 24 & $\begin{array}{l}\text { NSU Microfinance Bank } \\
\text { Limited }\end{array}$ & $\begin{array}{l}\text { NSU Community } \\
\text { Bank }\end{array}$ & $\begin{array}{c}\text { Orieagu-Umuahia Road, } \\
\text { Umuakagu Nsu, Ehime Mbano } \\
\text { Lga. }\end{array}$ & OKIGWE \\
\hline 25 & $\begin{array}{l}\text { NTUEKE Microfinance } \\
\text { Bank Limited }\end{array}$ & $\begin{array}{c}\text { NTUEKE } \\
\text { Community Bank }\end{array}$ & $\begin{array}{c}\text { Ntueke-Dikenfafi, Urualla, Imo } \\
\text { State }\end{array}$ & Orlu \\
\hline 26 & $\begin{array}{c}\text { NUMO Microfinance } \\
\text { Bank Limited } \\
\end{array}$ & $\begin{array}{c}\text { UMUNUMO } \\
\text { Community Bank } \\
\end{array}$ & $\begin{array}{l}\text { Umueze Umunumo Ehime, } \\
\text { Ehime Mbano Lga, Imo State }\end{array}$ & OKIGWE \\
\hline 27 & $\begin{array}{c}\text { NWABOSI Microfinance } \\
\text { Bank Limited } \\
\end{array}$ & $\begin{array}{c}\text { NWABOSI } \\
\text { Community Bank } \\
\end{array}$ & $\begin{array}{l}\text { Isiekenesi, Ideato Sough Lga, } \\
\text { Imo State } \\
\end{array}$ & Orlu \\
\hline 28 & $\begin{array}{c}\text { OBODOUKWU } \\
\text { Microfinance Bank } \\
\text { Limited } \\
\end{array}$ & $\begin{array}{l}\text { OBODOUKWU } \\
\text { Community Bank }\end{array}$ & Ideato Norht Lga, Imo State & Orlu \\
\hline 29 & $\begin{array}{l}\text { OGBE-AHIARA } \\
\text { Microfinance Bank } \\
\text { Limited } \\
\end{array}$ & $\begin{array}{l}\text { OGBE Community } \\
\text { Bank }\end{array}$ & $\begin{array}{c}\text { Onugot-Hse, Afor Ogbe Market, } \\
\text { P.O.Box 54, Ogbe Ahiara, } \\
\text { Ahiazu Mbaise, Imo State }\end{array}$ & Owerri \\
\hline 30 & $\begin{array}{l}\text { OGBERURU } \\
\text { Microfinance Bank } \\
\text { Limited } \\
\end{array}$ & $\begin{array}{c}\text { OGBERURU } \\
\text { Community Bank }\end{array}$ & $\begin{array}{l}\text { Eke Market Square, Ogberuru, } \\
\text { Imo }\end{array}$ & Orlu \\
\hline 31 & $\begin{array}{l}\text { OKIGWE INUDSTRIAL } \\
\text { MFB Limited }\end{array}$ & $\begin{array}{l}\text { OKIGWE } \\
\text { INUDSTRIAL CB }\end{array}$ & $\begin{array}{c}\text { 141, Owerri Road, Okigwe, Imo } \\
\text { State }\end{array}$ & OKIGWE \\
\hline 32 & $\begin{array}{l}\text { OKPORO Microfinance } \\
\text { Bank Limited }\end{array}$ & $\begin{array}{c}\text { OKPORO } \\
\text { Community Bank }\end{array}$ & $\begin{array}{l}\text { Okporo Postal Agency Building, } \\
\text { Okporoorlu Lga, }\end{array}$ & Orlu \\
\hline 33 & $\begin{array}{l}\text { OMUMA Microfinance } \\
\text { Bank Limited }\end{array}$ & $\begin{array}{c}\text { OMUMA } \\
\text { Community Bank }\end{array}$ & $\begin{array}{c}\text { Bank House, Omuma Market } \\
\text { Square, P.O.Box 7, Sub-Post } \\
\text { Office, Oru East Lga, Omuma, } \\
\text { Imo State }\end{array}$ & Orlu \\
\hline 34 & $\begin{array}{l}\text { ONIMA Microfinance } \\
\text { Bank Limited }\end{array}$ & $\begin{array}{l}\text { ONICHA-AMAURE } \\
\text { CB }\end{array}$ & $\begin{array}{l}\text { Onicha Ezinihitte Mbaise Lga, } \\
\text { Imo State }\end{array}$ & Owerri \\
\hline 35 & $\begin{array}{l}\text { ORSUIHITEUKWA } \\
\text { Microfinance Bank } \\
\text { Limited }\end{array}$ & $\begin{array}{l}\text { ORSUIHITEUKWA } \\
\text { CB }\end{array}$ & $\begin{array}{c}\text { Ekeututu Market Sq, } \\
\text { Orshihiteukwa, Orsu, Lga, }\end{array}$ & Orlu \\
\hline 36 & $\begin{array}{l}\text { OSINA Microfinance } \\
\text { Bank Limited }\end{array}$ & $\begin{array}{l}\text { OSINA Community } \\
\text { Bank }\end{array}$ & $\begin{array}{l}\text { Afor Osina, Ideato North Lga, } \\
\text { Imo State }\end{array}$ & Orlu \\
\hline 37 & $\begin{array}{l}\text { UMUHU OKABIA } \\
\text { Microfinance Bank } \\
\text { Limited }\end{array}$ & $\begin{array}{l}\text { UMUHU Community } \\
\text { Bank }\end{array}$ & $\begin{array}{l}\text { United Citizen Hall, Umuhu } \\
\text { Okabi, Orsu Lga, Imo State }\end{array}$ & Orlu \\
\hline 38 & $\begin{array}{l}\text { UNIQUE TRUST } \\
\text { Microfinance Bank } \\
\text { Limited }\end{array}$ & $\begin{array}{c}\text { UMUAKA } \\
\text { Community Bank }\end{array}$ & $\begin{array}{l}\text { Umuaka Youth Crusade Civic } \\
\text { Hall Building, Afor Umuaka, } \\
\text { Njaba Lga, Imo State }\end{array}$ & Orlu \\
\hline 39 & $\begin{array}{l}\text { URUALLA Microfinance } \\
\text { Bank Limited }\end{array}$ & $\begin{array}{c}\text { URUALLA } \\
\text { Community Bank }\end{array}$ & $\begin{array}{l}\text { Civic Centre Complex, Urualla, } \\
\text { Ideato North Lga. }\end{array}$ & Orlu \\
\hline 40 & $\begin{array}{l}\text { UVURU Microfinance } \\
\text { Bank Limited }\end{array}$ & $\begin{array}{l}\text { UVURU Community } \\
\text { Bank }\end{array}$ & $\begin{array}{c}\text { Orie Uvuru Market Square, } \\
\text { Mbaise, Imo State }\end{array}$ & Owerri \\
\hline
\end{tabular}

Source: Other Financial Institutions Department of CBN, 2007. 


\section{ANNEX 3}

\begin{tabular}{|c|c|c|}
\hline RANK & STATE & GDP (PPP\$) \\
\hline 1. & Lagos & $33,679,258,023$ \\
\hline 2. & Rivers & $21,073,410,422$ \\
\hline 3. & Delta & $16,749,250,544$ \\
\hline 4. & Oyo & $16,121,670,484$ \\
\hline 5. & Imo & $14,212,637,486$ \\
\hline 6. & Kano & $12,393,103,864$ \\
\hline 7. & Edo & $11,888,446,884$ \\
\hline 8. & Akwa Ibom & $11,179,887,963$ \\
\hline 9. & Ogun & $10,470,415,017$ \\
\hline 10. & Kaduna & $10,334,763,785$ \\
\hline 11. & Cross River & $9,292,059,207$ \\
\hline 12. & Abia & $8,687,442,705$ \\
\hline 13. & Ondo & $8,414,302,623$ \\
\hline 14. & Osun & $7,280,597,521$ \\
\hline 15. & Benue & $6,864,209,262$ \\
\hline 16. & Anambra & $6,764,219,562$ \\
\hline 17. & Katsina & $6,022,655,197$ \\
\hline 18. & Niger & $6,002,007,080$ \\
\hline 19. & Bornu & $5,175,165,142$ \\
\hline 20. & Plateau & $5,154,059,937$ \\
\hline 21. & Sokoto & $4,818,615,261$ \\
\hline 22. & Bauchi & $4,713,858,180$ \\
\hline 23. & Kogi & $4,642,794,262$ \\
\hline 24. & Adamawa & $4,582,045,246$ \\
\hline 25. & Enugu & $4,396,590,769$ \\
\hline 26. & Bayelsa & $4,337,065,923$ \\
\hline 27. & Zamfara & $4,123,829,498$ \\
\hline 28. & Kwara & $3,841,827,534$ \\
\hline 29. & Taraba & $3,397,790,217$ \\
\hline 30. & Kebbi & $3,290,847,166$ \\
\hline 31. & Nassarawa & $3,022,828,885$ \\
\hline 32. & Jigawa & $2,988,014,405$ \\
\hline 33. & Ekiti & $2,848,372,512$ \\
\hline 34. & Ebonyi & $2,732,472,739$ \\
\hline 35. & gombe & $2,500,467,306$ \\
\hline \multirow[t]{2}{*}{36.} & Yobe & $2,011,499,081$ \\
\hline & FCT & $5,010,968,012$ \\
\hline
\end{tabular}

Source: Conback Global Income Distribution Database, 2008.

\section{References}

[1] Adjei J. K., Arun T., Hossain F. (2009). The role of microfinance in asset building and poverty reduction: the case of Sinapi Aba Trust of Ghana. Manchester: Brooks World Poverty Institute.

[2] Ashraf N., Gine X., Karlan D. (2008). Finding missing markets (and a disturbing epilogue): evidence from an export crop adoption and marketing intervention in Kenya. Policy Research Working Paper 4477. Washington, DC: The World Bank Development Research Group. 
[3] Banerjee A., Duflo E., Glennerster R., Kinnan C. (2009). "The Miracle of Microfinance? Evidence from a Randomised Evaluation" Department of Economics, Massachusetts Institute of Technology (MIT) Working Paper, May.

[4] Brau J. C., Woller G. M., Journal of Entrepreneurial Finance and Business Ventures 9(1) (2004) 1-26.

[5] Central Bank of Nigeria (2005). Microfinance Policy, Regulatory and Supervisory Framework for Nigeria. Abuja, December.

[6] Chowdhury A. (2009). Microfinance as a Poverty Reduction Tool; A Critical Assessment. DESA Working Paper No. 89ST/ESA/2009/DWP/89 December

[7] Hulme D. (1997). Impact assessment methodologies for microfinance: a review. CGAP Working Group Impact Assessment Methodologies: Report of Virtual Meeting (mimeo).

[8] Hulme D., World Development 28(1) (2000) 79-88.

[9] Hulme D., Mosley P. (1996). Finance Against Poverty. Routledge, London.

[10] IPAR (2007). Poverty Reduction through Enhance Access to Financial Service: Case study of Botswana. Kenya and Namibia. Occasional paper No. 010/2007.

[11] Makina D., Malobola L. M., Development Southern Africa 21(5) (2004) 799-814.

[12] Microsoft Corporation (2009). Microsoft Encarta Premium Suite 2009 (Software).

[13] Ministry of Land Survey and Urban Planning (1992). Area of Imo State by LGA, Government Printer, Owerri.

[14] National Bureau of Statistics (NBS) (2007). Provisional of State and Local Government Totals of the 2006 Population Census of the Federal Republic of Nigeria. www.nigerianstat.gov.ng

[15] Report of United Nations (1995). Information is available www.laghuudyog.com/schemes/microfinance.htm

[16] Roodman D, Morduch J (2009) The impact of micro-credit on the poor in Bangladesh: revisiting the evidence (Working paper no 174). Washington DC: Centre for Global Development.

[17] Sebstad J., Cohen M. (2000). Microfinance, risk management and poverty. Synthesis report. Washington, DC: AIMS.

[18] Soludo C. C. (2008). Financing Imo State towards Greatness. Public Lecture delivered to mark the one year anniversary of the Executive Governor of Imo State, Chief Ikedi Ohakim: Imo Concorde Hotel, Owerri May 27.

[19] Westover J. (2008). The record of microfinance: the effectiveness/ ineffectiveness of microfinance programs as a means of alleviating poverty. Electronic Journal of Sociology. http://www.sociology.org/content/2008/_westover_finance.pdf

[20] World Bank (2007). Finance for all? Policies and pitfalls in expanding access. Washington DC: World Bank.

[21] Yahaya K. A, Osemene O. F., Abdulraheem A., Global Journal of Management and Business Research 11(4) (2011) Version 1.0 March. 
[22] Tomáš Hes, Anna Poledňáková, International Letters of Social and Humanistic Sciences 2 (2013) 18-31.

[23] Taiwo Adewale Muritala, Ismail O. Fasanya, International Letters of Social and Humanistic Sciences 2 (2013) 39-50.

[24] Mohsen Mehrara, Maysam Musai, International Letters of Social and Humanistic Sciences 5 (2013) 55-62.

[25] Petter Gottschalk, Lars Glasø, International Letters of Social and Humanistic Sciences 5 (2013) 63-78.

[26] Goran Rajović, Jelisavka Bulatović, International Letters of Social and Humanistic Sciences 6 (2013) 49-61.

[27] Bahram Meihami, Zeinab Varmaghani, Hussein Meihami, Mohammad Khaledian, International Letters of Social and Humanistic Sciences 7 (2013) 33-42.

[28] Tomáš Hes, Alena Neradová, Karel Srnec, International Letters of Social and Humanistic Sciences 7 (2013) 55-75.

[29] Tomáš Hes, Alena Neradová, Karel Srnec, International Letters of Social and Humanistic Sciences 7 (2013) 76-85.

[30] Kinga Dziwańska, International Letters of Social and Humanistic Sciences 7 (2013) 96-112.

[31] Jacek Tittenbrun, International Letters of Social and Humanistic Sciences 11 (2013) 10-34.

[32] Philip Usman Akor, Julie Udensi, International Letters of Social and Humanistic Sciences 2 (2014) 97-109.

[33] Adoga James Ada, International Letters of Social and Humanistic Sciences 3 (2014) 45-52.

[34] Bahram Meihami, Hussein Meihami, International Letters of Social and Humanistic Sciences 3 (2014) 80-91.

[35] Jacek Tittenbrun, International Letters of Social and Humanistic Sciences 2 (2014) 20-40. 